defect has been studied by a number of fruitful techniques and its genetic aspect is much better understood than that of mental disorder. A number of syndromes arising from chromosome defects, such as Klinefelter's syndrome (the presence of an excess sex chromosome) and Down's disease (21-trisomy), are well characterized. Not surprisingly, what the report calls "mental retardation of unknown aetiology" is poorly understood, although here the statistical methods of population genetics can be of great value. These methods have made it possible to divide the cases of retardation into two main groups-one in which it seems that there is a strong genetic involvement and one with a low risk. Genetic factors are responsible for many cases in the group at high risk. These include at least one chromosome abnormality and a number of single recessive genes with high penetrance.

The WHO group puts forward a number of proposals for topics on which work should be concentrated. It calls for research into the frequency of chromosome abnormalities and the relationship of these abnormalities with mental disorder, particularly from the biochemical point of view. It would like to see more work on twins, preferably on an international scale, including studies of twins separated in early life, and on adopted children and their families. It also thinks workers should hurry to examine inbred populations before they are submerged by admixture and the spread of urbanization.

\section{New Ghost Town}

THE new town promised by the Minister of Housing and Local Government in North Buckinghamshire will not only be the largest in the United Kingdom but probably the most diffuse as well. By the end of the century it will hold 250,000 people from London at an overall density of about 11 to the acre. Most of the new town, to be called Milton Keynes, will be between the trunk roads $\mathrm{Ml}$ and $\mathrm{A} 5$, and it will absorb the existing towns of Bletchley, Wolverton, and Stony Stratford. The original plans specified an area of 25,200 acres, but the report of the public inquiry conducted by Mr. G. C. Godber, an independent inspector appointed by the ministry, has persuaded Mr. Greenwood to reduce this by 3,300 acres. Observing that the site is roughly as large as Bristol (population $434,000)$ and substantially larger than Coventry $(327,000)$, the inspector reported that "The objectors were not convinced and I am certainly not convinced that it can be right to take so low a density as a target One thing is certain-the plan will fill whatever land is designated, and it is not right to sacrifice good farms and good farmers needlessly to make a planners picture."

Not all the planners are cock-a-hoop at the opportunity offered by the minister, however. There are two schools of thought--at least--on town density. One, in which architects are conspicuous, holds that high densities are necessary both as a discipline and to create what is known as urbanism (or occasionally urbanity, although that is usually taken to mean some. thing quite different). This point of view is coloured by sociological studies such as that of Michael Young and Peter Wilmott-Family and Kinship in East London-who showed that when people are moved. from a close-knit community (Bethnal Green) to a suburban housing estate (Woodford), their strong sense of community is left behind. Among the greater population densities used, with the support of many local authorities and the Ministry of Housing, is that at Cumbernauld new town in Scotland, where 85 people are housed on each acre.

The other point of view is probably put most forcefully, and certainly most often, by the Town and Country Planning Association, whose attack is directed chiefly at flats, which are said to be unpopular with tenants, and more expensive to build and maintain than houses. Certainly the association is convinced that only about 5 per cent of British people want flats, and that even this minority taste is probably declining. Bungalows, semi-detached and detached houses vie for popularity. To those for whom this presents a doleful vision of mile upon mile of suburban houses and bungalows, combining the worst features of American urban sprawl and British design, the association says that urban sprawl is not necessarily the result of low density housing but simply of bad design.

The aesthetic and sociological argument is a fascinating one, but may become an irrelevance, if it has not already done so. The South-East Study (H.M.S.O., 15s., 1964) estimates that the population increase of South-East England is likely to be $\mathbf{3 . 5}$ million by 1981. Housing this increase in towns as thinly spread as Milton Keynes would need an area of about 310,000 acres-greater than that of Bedfordshire. Nobody dares to think about A.D. 2000, when the new town will have reached its leisurely target.

\section{Cinnabar with Everything}

THe production of gold from base metals has long been known as the ambition of the alchemists, but they had another preoccupation - the lengthening of life. Chinese alchemy in particular was almost totally dedicated to this end, as can be told from $A$ History of Ideas about the Prolongation of Life (Trans. Amer. Phil. Soc., N.S., 56, part 9; 1966).

One of the principles of the Chinese alchemists was a kind of vitalism, which implied that certain substances contain the essence of life and can be used to produce medicines which help to prolong it. Certain characteristics were considered necessary for a substance to be a vitalizer; these included being shining, fluid, strong to the taste and blood red in colour. The alchemists had a list of materials which possessed the vitalizing property, and there was a heirarchy with minerals at the top and herbs at the bottom. Drugs of vegetable origin were inefficient vitalizers; they can only decompose and decay, but the minerals had many of the necessary characteristics. The most valuable were the rare minerals. Silver, gold and cinnabar were at the top of the list; mercuric sulphide occupied a supreme position in Chinese alchemy, although it was only of minor importance in other cultures. Cinnabar had the blood-red colouring which bestowed life giving qualities, which were already recognized, for neolithic people in China had deposited vermilion pigment with their dead. The change of cinnabar, on heating, to mercury, and the conversion of this to mercuric oxide which sublimes back to mercury, showed the alchemists a seemingly endless cycle involving "living" red cinnabar and "living" fluid mercury. This represented longevity, which 